\title{
LEMBAGA ADAT DAN EKSISTENSI MASYARAKAT ADAT NEGERI LAFA KECAMATAN TELUTI KABUPATEN MALUKU TENGAH
}

\author{
Jacob Serumena, Hermien L. Soselisa, Wellem R. Sihasale \\ Program Studi Sosiologi Fakultas Ilmu Sosial dan Ilmu Politik \\ Universitas Pattimura \\ hermien2018@gmail.com, wem.sisasale1@gmail.com
}

\begin{abstract}
Abstrak
Studi ini bertujuan untuk mengetahui dan mendeskripsikan tentang lembaga adat dan eksistensi masyarakat adat di Negeri Lafa Kecamatan Teluti Kabupaten Maluku Tengah. Metode penelitian yang digunakan adalah metode penelitian kualitatif. Hasil penelitian menunjukkan bahwa keberadaan lembaga-lembaga adat dalam kehidupan masyarakat adat dapat menjadi sarana untuk mengawasi dan mengatur pola-pola perilaku seluruh anggota masyarakat adat. Namun, realitas di lapangan saat ini menunjukkan bahwa lembaga-lembaga adat di dalam kehidupan masyarakat adat belum mampu melaksanakan tugas dan perannya dengan baik sehingga menyebabkan munculnya berbagai masalah adat seperti, masalah batas-batas tanah petuanan dan masalah pemilihan raja. Guna mengatasi dan meminimalkan berbagai masalah adat yang muncul maka perlu adanya peningkatan peran lembaga-lembaga adat dan kesadaran seluruh anggota masyarakat adat untuk lebih mengenal serta memaknai nilai-nilai yang terkandung dalam adat-istiadat yang dimiliki. Hal ini penting dilakukan supaya pola-pola perilaku seluruh anggota masyarakat adat dapat mencerminkan dan memperkokoh eksistensi masyarakat adat. Masih kurangnya peran lembaga adat dimaksud tampak pada Negeri Lafa sebagai salah satu negeri adat yang terdapat di Pulau Seram. Lembaga adat di Negeri Lafa, seperti lembaga saniri hingga saat ini belum mampu melaksanakan perannya dengan baik. Hal ini disebabkan oleh masih kurang terjalin interaksi antara anggota saniri yang terdiri dari para orang tua dan anak muda sehingga menghambat peran lembaga saniri tersebut
\end{abstract}

Kata Kunci: masyarakat adat, lembaga adat, generasi muda.

This study aims to identify and describe the customary institutions and existence of indigenous peoples in Negeri Lafa, Teluti District, Central Maluku Regency. The research is qualitative research methods. The result shows that the existence of customary institutions in the lives of indigenous peoples can be a tool to monitor and regulate the behaviour patterns of all members of indigenous peoples. However, the current reality appears that the existence of customary institutions in the lives of indigenous peoples has not been able to carry out their duties and roles properly so that it has led to the emergence of various customary problems such as problems with the boundaries of land ownership and the problem of choosing the king. In order to overcome and minimize the various customary problems that arise, it is necessary to increase the role of customary institutions and the awareness of all members of indigenous peoples to know and to interpret the values contained in their customs. This is important to do, so that the behaviour patterns of all members of indigenous peoples can reflect and can strengthen the existence of the community. There is still a lack of the role of the intended customary institutions as seen in Negeri Lafa as one of the traditional costumary village on Seram Island. The traditional institutions in Negeri Lafa, such as saniri institutions, have not been able to carry out their roles properly. This is due to the lack of interaction between saniri members consisting of parents and young people, thus hampering the role of these saniri institutions.

Keywords: indigenous peoples, customary institutions, the younger generation. 


\section{Pendahuluan.}

Dalam realitasnya, setiap manusia hidup pada suatu lingkungan sosial budaya tertentu. Setiap lingkungan sosial budaya itu senantiasa memberlakukan adanya nilai-nilai sosial budaya yang dipedomani oleh warga masyarakatnya. Melalui proses belajar secara berkesinambungan setiap manusia akan menganut suatu nilai yang diperoleh dari lingkungannya. Nilai-nilai itu diadopsi dan kemudian diimplementasikan dalam suatu bentuk kebiasaan yaitu pola sikap dan perilaku sehari-hari. Dengan demikian pola perilaku seseorang dalam berinteraksi dengan orang lain, akan dipengaruhi oleh nilai-nilai yang diperoleh dari lingkungan sosial budayanya. Kekuatan nilai-nilai maupun segala sumberdaya sosial budaya membentuk dan mempengaruhi pola tingkah laku individu. Hal ini karena setiap individu memiliki lingkungan sosial budaya yang saling berbeda dengan yang lain maka situasi ini menghasilkan karakter sosial budaya setiap individu yang bersifat unik, khusus, dan berbeda dengan orang lain. Dalam konteks yang demikian, para ahli antropologi memiliki kesamaan pendapat mengenai tiga karakteristik budaya (Suranto, 2010:28): (1). Budaya bukan pembawaan sejak lahir melainkan dipelajari, (2). Berbagai bentuk budaya saling berhubungan-kalau salah satu aspek budaya tersentuh, yang lain ikut tersentuh, (3). Dimiliki bersama oleh anggota kelompok dan menjadi pembatas antara kelompok yang berbeda.

Banyaknya aspek budaya yang muncul dapat pula mempengaruhi pola tingkah laku manusia dalam masyarakat. Hal ini membuktikan bahwa nilai-nilai sosial budaya diajarkan dan diwariskan oleh lingkungan, baik lingkungan keluarga maupun lingkungan masyarakat. Dengan demikian, manusia dan kebudayaan merupakan suatu kesatuan yang tidak terpisahkan karena pendukung kebudayaan adalah manusia itu sendiri. Sekalipun manusia akan mati namun kebudayaan yang dimilikinya akan diwariskan pada keturunannya sehingga dalam kehidupan bersama sebagai suatu masyarakat, kebudayaan akan selalu terpelihara dari generasi ke generasi. Dalam upaya memelihara kebudayaan ini maka manusia dalam kehidupan bermasyarakatnya membutuhkan adanya lembagalembaga sosial budaya yang mampu menjembatani dan mewadahi berbagai nilai-nilai budaya untuk menjadi pedoman hidup bersama.

Keberadaan lembaga-lembaga tersebut, sebenarnya juga sebagai sebuah badan untuk melaksanakan sistem norma atau aturan yang berlaku dalam masyarakat. Menurut Berger lembaga merupakan suatu prosedur yang menyebabkan perbuatan manusia ditekan oleh pola tertentu dan dipaksa bergerak melalui jalan yang dianggap sesuai dengan 
keinginan masyarakat. Sedangkan menurut W. Hamilton, lembaga merupakan tata cara kehidupan kelompok yang apabila dilanggar akan dijatuhi pelbagai derajat sanksi (Basrowi, 2005:92). Demikian maka, lembaga dapat memberikan arah untuk mengatur pola-pola perilaku dan tindakan setiap individu dalam masyarakat.

Dalam perspektif sosiologi, keberadaan lembaga yang dimaksud berkenaan dengan sebuah lembaga sosial. Istilah lembaga sosial (social institution) lebih menunjuk pada adanya unsur-unsur yang mengatur perilaku warga dalam kehidupan sosial masyarakat. Artinya, keberadaan lembaga sosial ini mengarah pada suatu bentuk perilaku sosial anggota masyarakat dalam kehidupan bersama, sekaligus juga mengandung pengertian yang abstrak perihal adanya norma-norma dan peraturan-peraturan tertentu yang menjadi ciri lembaga sosial tersebut.

Sejalan dengan hal tersebut Alvin L Bertrand (dalam Rusdiyanta, 2009:71) menyatakan bahwa lembaga sosial pada hakekatnya adalah kumpulan-kumpulan dari norma-norma sosial (struktur sosial) yang telah diciptakan untuk dapat melaksanakan fungsi masyarakat. Sementara menurut Polak (dalam Basrowi, 2005:92) bahwa lembaga sosial (social institution) adalah suatu kompleks atau sistem peraturan-peraturan dan adat istiadat yang mempertahankan nilai-nilai yang penting.

Dalam konteks yang demikian maka keberadaan lembaga sosial yang dimaksud terkait dengan lembaga adat pada suatu masyarakat adat, khususnya di Maluku. Lembagalembaga adat tersebut seperti lembaga pemerintahan negeri, lembaga saniri lengkap atau lembaga saniri besar. Keberadaan lembaga-lembaga adat ini tidak terlepas dari kehidupan masyarakat pada suatu negeri adat. Artinya, keberadaan lembaga adat dalam sebuah kehidupan masyarakat adat memiliki peran yang sangat penting untuk mengatur pola-pola perilaku dan tindakan dari warga masyarakatnya. Namun, dalam realitas kehidupan masyarakat adat yang tampak saat ini, lembaga adat dalam eksistensinya seakan belum mampu melaksanakan perannya dengan baik sehingga menyebabkan muncul berbagai masalah yang tentu saja dapat berpengaruh terhadap eksistensi masyarakat adatnya.

Lembaga-lembaga adat sebagaimana yang disebutkan di atas memiliki tugasnya masing-masing. Misalnya saniri lengkap bertugas membuat perundang-undangan pemerintah negeri, mengadakan musyawarah untuk membahas hal-hal yang penting, membuat garis-garis kebijakan dan mengeluarkan peraturan. Begitu pula dengan saniri besar yang bertugas untuk membuat musyawarah negeri untuk membicarakan sesuatu yang dianggap penting bagi kelangsungan hidup negeri. Saniri besar juga berhak untuk 
mencabut peraturan negeri apabila dipandang perlu demi kepentingan negeri (Sihasale, 2005:85).

Tugas lembaga-lembaga adat tersebut termanifestasi dalam dinamika kehidupan masyarakat adat, khususnya di Maluku. Lembaga-lembaga adat yang tumbuh dan berkembang tanpa disadari telah menjadi bagian dari identitas diri masyarakat adat. Hal ini karena dalam eksistensi masyarakat adat, muncul lembaga-lembaga adat yang berfungsi sebagai wadah untuk mengatur pola-pola perilaku anggota masyarakat adat. Eksistensi masyarakat adat yang seringkali diwarnai dengan munculnya berbagai masalah yang cenderung melemahkan atau bahkan menghancurkan nilai-nilai adat telah mendorong peningkatan peran lembaga-lembaga adat.

Realitas sosial budaya yang tampak saat ini bahwa dalam kehidupan masyarakat adat, lembaga-lembaga adat yang ada seakan hanya sebagai simbol yang melengkapi struktur pemerintahan adat. Berbagai tugas yang harusnya dilakukan untuk menjawab kebutuhan masyarakat adat seringkali tidak dilaksanakan ataupun kalau dilaksanakan dapat dikatakan masih belum maksimal. Realitas yang demikian menyebabkan munculnya berbagai masalah adat di antaranya masalah batas tanah petuanan dan masalah pemilihan raja. Masalah-masalah seperti ini yang seringkali membuat masyarakat adat berada dalam konflik, baik antara sesama mereka atau dengan masyarakat adat lainnya. Hal ini pun lebih diperburuk oleh sikap dan perilaku anggota masyarakat adat yang seringkali bertentangan dengan nilai-nilai yang terkandung dalam adat-istiadat yang dimiliki.

Pada era modernisasi saat ini, anggota-anggota masyarakat adat, baik generasi muda atau generasi tua (para orang tua) dalam bersikap atau berperilaku cenderung mengikuti perkembangan zaman sehingga nilai-nilai adat-istiadat tidak lagi ditaati atau bahkan diabaikan begitu saja. Kondisi seperti ini tentu saja sangat dilematis sebab pada satu sisi generasi muda yang merupakan pewaris dan penerus adat-istiadat seakan terbawa oleh suasana perkembangan arus modernisasi yang semakin canggih sehingga mereka lupa akan tanggung jawabnya sebagai anak adat. Pada sisi lain, generasi tua (para orang tua) ada dalam kesibukannya sendiri yaitu melaksanakan tanggung jawabnya dengan bekerja untuk dapat memenuhi kebutuhan hidup keluarga sehingga kewajiban untuk mewariskan adat-istiadat dan nilai-nilainya kepada anak-anak menjadi tidak terlaksana atau kalau pun terlaksana mungkin hanya sebagian kecil saja.

Eksistensi masyarakat adat saat ini dapat dikatakan berada dalam kondisi bahwa masih banyak generasi muda dan sebagian dari para orang tua yang tidak mengetahui 
tentang adat-istiadat yang dimiliki. Kenyataan yang seringkali dihadapi bahwa mereka yang tidak mengetahui tentang adat-istiadatnya ketika ditanya, mereka tidak bisa menjawab dan akan mengarahkan orang yang bertanya kepada anggota masyarakat adat lainnya yang dianggap mengetahui tentang adat-istiadat tersebut. Hal ini tentu saja harus dilakukan dengan peningkatan peran lembaga-lembaga adat sehingga seluruh anggota masyarakat adat dapat mengetahui adat-istiadat yang dimiliki dan berusaha untuk menjaga serta melestarikan nilai-nilai yang terkandung di dalamnya. Apabila peran lembagalembaga adat ini dapat dilakukan dengan baik maka tidak perlu lagi ada pertanyaan tentang eksistensi masyarakat adat sebab sampai kapan pun masyarakat adat akan tetap eksis. Hal ini sebagaimana yang diungkapkan Watloly (2007:9) bahwa analisis eksistensi mereka tidak hanya membantu untuk mengungkap atau menjawab pertanyaan tentang apa (esensi)-nya tetapi lebih menukik pada substansi sosialnya untuk menjawab pertanyaan mengenai siapa, mengapa dan bagaimana hakikat diri mereka.

Penjelasan di atas sebagaimana yang terlihat pada kehidupan masyarakat adat Negeri Lafa Kecamatan Teluti Kabupaten Maluku Tengah. Negeri Lafa yang merupakan salah satu negeri adat memiliki ciri atau karakteristik yang tidak jauh berbeda dengan negeri-negeri adat lainnya di Maluku. Dalam Peraturan Daerah Kabupaten Maluku Tengah Nomor 01 Tahun 2006 Tentang Negeri, tercantum bahwa Negeri adalah kesatuan mayarakat hukum adat yang bersifat genealogis yang memiliki batas wilayah, berwenang mengatur dan mengurus kepentingan masyarakat setempat berdasarkan hak asal usul dan adat istiadat setempat di Kabupaten Maluku Tengah yang diakui dan dihormati dalam sistem Pemerintahan Negara Kesatuan Republik Indonesia (NKRI).

\section{Metode Penelitian.}

Penelitian dengan topik tentang lembaga adat dan eksistensi masyarakat adat di negeri adat pada Kecamatan Teluti Kabupaten Maluku Tengah ini menggunakan jenis pendekatan kualitatif. Dengan menggunakan pendekatan kualitatif maka peneliti berupaya untuk mendalami realita lembaga adat dan eksistensi masyarakat adat Negeri Lafa dan menemukan berbagai data atau informasi penting yang dapat digunakan untuk mendeskripsikan realita tersebut.

Lokasi yang dijadikan sebagai lokus pengumpulan data tentang lembaga adat dan eksistensi masyarakat adat adalah Negeri Lafa. Peneliti sengaja memilih Negeri Lafa 
sebagai lokasi penelitian karena dari hasil pengamatan awal ditemukan adanya berbagai masalah yang terkait dengan adat-istiadat dalam masyarakat. Hal ini didukung pula oleh kurangnya peran lembaga-lembaga adat di Negeri Lafa sehingga menyebabkan masalah yang ada semakin kompleks.

Guna memenuhi kebutuhan data maka dalam penelitian ini informan diambil dari masyarakat Negeri Lafa, yaitu pejabat raja, staf pemerintaha negeri, kepala-kepala soa, anggota saniri, serta anggota masyarakat. Informan merupakan salah satu elemen penting dalam penelitian kualitatif. Menurut Moleong (2005:132-133), informan adalah orang yang dimanfaatkan untuk memberikan informasi tentang situasi dan kondisi latar belakang penelitian. Usaha untuk menemukan informan dapat dilakukan dengan cara, (1) melalui keterangan orang yang berwenang, baik secara formal (pemerintah) maupun secara informal (pimpinan masyarakat, seperti tokoh masyarakat, pimpinan adat dan lain-lain), (2) melalui wawancara pendahuluan yang dilakukan.

\section{Temuan dan Pembahasan.}

Negeri Lafa secara administratif termasuk dalam wilayah Kecamatan Telutih Kabupaten Maluku Tengah, tepatnya terletak di bagian timur kabupaten tersebut. Negeri Lafa terdiri dari 7 Rukun Tetangga (RT), dengan luas wilayah sebesar 129 hektar. Luas kawasan permukiman sebesar $6 \mathrm{Ha}$ dan memiliki garis pantai sepanjang $2 \mathrm{Km}$. Negeri Lafa memiliki batas-batas wilayah sebagai berikut: sebelah Utara berbatasan dengan Taman Nasional Manusela, sebelah Selatan berbatasan dengan Laut Banda, sebelah Barat berbatasan dengan Negeri Wolu, dan sebelah Timur berbatasan dengan Negeri Tehua.

Jumlah penduduk Negeri Lafa pada tahun 2015 tercatat sebanyak 1065 jiwa yang terdiri dari jumlah penduduk dengan jenis kelamin laki-laki sebanyak 561 jiwa dan penduduk dengan jenis kelamin perempuan sebanyak 504 jiwa. Jumlah penduduk Negeri Lafa ini apabila dibagi lagi perjenjang usia maka penduduk dengan usia antara 0-5 tahun berjumlah 175 jiwa, penduduk dengan usia 6-14 tahun berjumlah 225 jiwa, penduduk dengan usia 15-45 tahun berjumlah 472 jiwa, dan penduduk usia 45 tahun ke atas berjumlah 193 jiwa.

Negeri Lafa sebagai salah satu negeri adat di Maluku sudah ada sejak tahun 1798. Cikal bakal negeri ini dibentuk oleh Selumena yang keluar meninggalkan Supa Maraina di kaki Gunung Murkele, menuju ke arah selatan untuk mencari kehidupan baru di wilayah pemukiman baru. Ia kemudian menetapkan beberapa aturan adat yang di dalamnya 
terdapat larangan dan sanksi serta perintah. Ia kemudian naik ke kampong asal untuk mengajak datuk Tehuayo untuk bergabung dengannya. Setelah datuk Tehuayo mempelajari aturan yang dibuat oleh Selumena, iapun menyetujui untuk bergabung. Setelah itu, bergabung pula datuk Ilela dan Poliay yang datang juga dari Maraina. Datuk Poliay kemudian merubah namanya menjadi Silawane. Keempat kelompok datuk inilah yang membentuk Negeri Lafa. Selumena sebagai orang pertama memegang jabatan sebagai raja tanah atau raja adat. Dalam pengukuhan raja secara adat, ia yang berhak mengambil sumpah raja baru, dan hal ini masih berlangsung hingga kini. Di kemudian hari bergabung pula marga-marga lain yang berasal dari daerah lain di Seram maupun dari luar Seram. Mereka dimasukkan ke dalam keempat kelompok klan asli yang membentuk Negeri Lafa.

Sebagai suatu negeri adat maka Negeri Lafa merupakan salah satu daerah otonom yang berada dalam wilayah administratif Kabupaten Maluku Tengah. Sebagai daerah otonom adat maka Negeri Lafa memiliki kewenangan untuk mengurus pemerintahan dan segala kepentingan masyarakatnya. Negeri Lafa dalam eksistensinya memiliki tanggung jawab penuh terhadap kelangsungan hidup masyarakatnya. Guna mewujudkan tanggung jawab tersebut dibutuhkan adanya peningkatan peran lembaga-lembaga adat. Lembagalembaga adat yang merupakan bagian integral dalam kehidupan masyarakat adat Negeri Lafa dapat menjadi sarana untuk menuntun dan mengatur pola-pola kehidupan setiap anggota masyarakat adat. Sehubungan dengan hal dimaksud, Lokollo (2012:312) menyatakan bahwa keberadaan, fungsi dan eksistensi negeri adat di Maluku didasarkan pada ciri kekhasan tersendiri, dengan pranata-pranata adat sebagai penuntun dalam kehidupan antar negeri-negeri adat. Pranata yang diciptakan berguna untuk menjaga terjaminnya tertib adat dalam masyarakat, bukanlah sesuatu yang statis. Sebagai bagian dari kebudayaan daerah Maluku maka pranata-pranata adat berubah sesuai perkembangan zaman.

Keberadaan lembaga-lembaga adat telah menunjukkan eksistensi masyarakat Negeri Lafa sebagai salah satu negeri adat di Maluku. Keberadaan lembaga-lembaga adat tersebut, bukan hanya untuk menunjukkan eksistensi masyarakat adat, tetapi lebih dari itu adalah untuk mengatur pola-pola kehidupan setiap warga masyarakat adat Negeri Lafa. Lembaga-lembaga adat dimaksud di antaranya saniri, saniri besar dan saniri lengkap yang memiliki perannya masing-masing. Peran lembaga-lembaga adat inipun, pada hakikatnya sama di setiap negeri adat di Maluku. Namun dalam kenyataan hidup 
masyarakat adat, masih ada lembaga-lembaga adat yang belum dapat melaksanakan perannya dengan baik. Kenyataan ini sebagaimana yang terjadi dalam kehidupan masyarakat adat Negeri Lafa.

Pada masyarakat adat Negeri Lafa, keberadaan lembaga-lembaga adat telah ada sejak dahulu dan keberadaannya seakan telah menjadi identitas diri setiap warga masyarakatnya. Namun sangatlah disayangkan ketika keberadaan lembaga-lembaga adat tersebut hanya sebagai simbol yang melengkapi struktur masyarakat adat Negeri Lafa. Hal ini disebabkan oleh mulai berkurangnya kesadaran warga terhadap pentingnya keberadaan lembaga-lembaga adat dan implementasi peran lembaga-lembaga adat dimaksud dalam kehidupan masyarakat adat. Kenyataan yang sering dijumpai dalam kehidupan masyarakat adat Negeri Lafa hingga saat ini adalah lembaga-lembaga adat belum mampu mengimplementasikan perannya dengan baik sehingga masih banyak masalah-masalah yang berhubungan dengan adat istiadat yang belum dapat diselesaikan oleh lembagalembaga adat tersebut. Masalah-masalah tersebut diantaranya seperti, masalah batas tanah antara warga, dan masalah dalam sistem pemerintahan adat, khususnya tentang pemilihan raja.

Masyarakat Negeri Lafa hingga saat ini belum memiliki seorang pemimpin negeri atau raja definitif. Hal ini disebabkan oleh adanya keinginan warga-warga lain yang bukan berasal dari mata rumah parentah untuk menjadi raja. Masyarakat Negeri Lafa mengenal adanya mata rumah parentah yang berada dalam soa parentah yang memiliki hak untuk menjadi raja secara turun-temurun. Apabila ada warga yang bukan berasal dari mata rumah parentah ingin menjadi raja, maka mereka harus meminta restu atau ijin dari mata rumah parentah. Cara seperti ini umumnya berlaku di setiap negeri-negeri adat dan diakui sepenuhnya oleh warga masyarakat adat.

Selain permasalahan di atas, di Negeri Lafa banyak generasi muda yang tidak mengetahui tentang adat istiadat dan nilai-nilai yang terkandung di dalamnya. Seperti contoh yang dapat disampaikan bahwa ada generasi muda yang ketika ditanya tentang apa itu saniri atau saniri negeri, mereka tidak dapat menjawabnya. Kenyataan seperti ini sangat disayangkan apabila melihat posisi generasi muda sebagai generasi penerus yang akan mewarisi semua adat istiadat dan nilai-nilainya. Ada juga kesenian-kesenian adat seperti tari-tarian yang hampir tidak lagi ditampilkan pada saat pelaksanaan acara-acara adat. Semua masalah yang disebutkan tanpa disadari telah mengganggu kenyamanan hidup dan seakan mempertanyakan eksistensi masyarakat adat Negeri Lafa. 


\subsection{Dinamika Kehidupan Sosial Budaya di Negeri Lafa.}

Negeri Lafa sebagai salah satu negeri adat memiliki masyarakat yang plural atau majemuk dari segi suku dan agama. Pada Negeri Lafa terdapat beberapa suku dan sub suku seperti Buton, Bugis, Cina, dan Kei, dan mereka merupakan pemeluk agama Kristen dan Islam. Walaupun mayoritas masyarakat Negeri Lafa adalah pemeluk agama Kristen Protestan namun kehidupan sosial antar warga selalu tampak harmonis dan tidak pernah terjadi konflik antar warga karena perbedaan tersebut. Keharmonisan warga masyarakat Negeri Lafa disebabkan oleh adanya relasi-relasi sosial yang terjalin dengan sangat baik antar sesama warga. Relasi-relasi sosial tersebut bukan hanya terjalin dalam kehidupan sehari-hari namun juga pada berbagai kegiatan atau aktivitas sosial budaya yang selalu dilakukan dan melibatkan seluruh warga masyarakat.

Kehidupan yang harmonis dengan terciptanya relasi-relasi sosial yang sangat baik antar sesama warga sebenarnya merupakan kebiasaan yang sudah ada sejak zaman leluhur. Pada zaman leluhur masyarakat Negeri Lafa, keharmonisan hidup dan relasirelasi sosial sudah dipraktekan dalam kehidupan sehari-hari sehingga di masa sekarang ini hal tersebut tidak lagi menjadi sesuatu yang luar biasa bagi warga masyarakat Negeri Lafa. Warga masyarakat Negeri Lafa memiliki pola relasi-relasi sosial yang sangat baik yang terwujud melalui aktivitas sosial budaya dalam kehidupan sehari-hari. Aktivitas sosial budaya dimaksud seperti kerja bakti membersihkan lingkungan dan acara menyambut tahun baru yang didalamnya ditampilkan tarian cakalele dari warga Negeri Lafa, acara soi-soi dari warga Negeri Lafa yang berasal dari Maluku Tenggara, serta pencak silat dari warga Negeri Lafa yang berasal dari Buton. Semua aktivitas sosial budaya tersebut melibatkan seluruh warga masyarakat Negeri Lafa, tidak membedabedakan suku dan agama.

Namun perlu diakui bahwa dalam kehidupan warga masyarakat Negeri Lafa saat ini, keharmonisan dan relasi-relasi sosial yang terjalin dengan sangat baik itu telah dipengaruhi oleh perilaku dan tindakan para pemuda Negeri Lafa yang dianggap telah melanggar nilai-nilai dan norma-norma adat. Para pemuda Negeri Lafa saat ini, umumnya tidak mengetahui dan memahami tentang adat-istiadat di negeri mereka. Mereka lebih memilih duduk-duduk sambil meminum minuman keras tradisional (sopi) daripada duduk-duduk untuk mendengarkan cerita para orang tua tentang adat-istiadat mereka. Kebiasaan mengkonsumsi minuman keras ini menyebabkan seringkali muncul 
kesalahpahaman yang berakhir dengan terjadinya konflik antar sesama mereka. Perilaku dan tindakan para pemuda telah mengganggu keamanan dan ketertiban lingkungan serta menyebabkan warga masyarakat menjadi tidak nyaman.

Apa yang dilakukan para pemuda dianggap sebagai bentuk pelanggaran terhadap nilai-nilai dan norma-norma adat yang berlaku di negeri mereka. Hal ini tentu sangat disayangkan mengingat para pemuda merupakan generasi penerus yang harus menjaga serta melestarikan nilai-nilai dan norma-norma adat tersebut. Selain itu, apa yang dilakukan para pemuda sangat mengecewakan warga masyarakat sebab sebagian dari mereka merupakan anggota lembaga saniri di Negeri Lafa. Kekecewaan warga masyarakat tentu sangat beralasan sebab bagi mereka, umumnya para pemuda masih belum mengetahui dan memahami tentang adat-istiadat yang berlaku di negeri mereka, terutama soal aturan-aturan adat dan bahasa adat.

Menurut Ajawaila (2005:175-176) generasi muda Maluku sekarang terutama mereka yang berdiam di kota tidak lagi mengetahui dan mengenal secara baik kebudayaan/adat Ambon. Mereka cenderung untuk mengikuti budaya modern sangat besar. Kecenderungan ini ternyata tidak hanya ditemui pada generasi muda yang hidup di kota, tetapi juga di negeri-negeri yang relative jauh dari pusat-pusat pemeritahan, ekonomi, dan pusat perumbuhan lain di tingkat provinsi, seperti halnya pada generasi muda di Negeri Lafa di ujung timur Kabupaten Maluku Tengah.

Sebagai negeri adat, Negeri Lafa memiliki aturan-aturan adat dan juga bahasa adat. Namun aturan-aturan adat dan bahasa adat ini umumnya hanya diketahui dan dipahami oleh para orang tua daripada para pemuda. Hal ini tentu sangat disayangkan mengingat posisi para pemuda juga termasuk dalam struktur keanggotaan lembaga saniri di Negeri Lafa yang seyogyanya berusaha untuk mengetahui dan memahami hal tersebut.

Senada dengan hal ini, Effendi (1987:42) menyebutkan bahwa, Saniri Negeri keanggotaannya terdiri dari pejabat-pejabat yang duduk dalam Saniri Rajapatti dan wakil dari soa-soa tetapi bukan kepala soa, kepala-kepala adat, dan tua-tua negeri seperti kepala-kepala soa tanah, tamaela ami haha, tukang, para cendikiawan, kewang darat, dan kewang laut, dan petugas-petugas di bidang kerohanian. Jumlah yang lazim adalah antara $12-15$ orang.

Lembaga saniri di Negeri Lafa memiliki keanggotaan yang merupakan perwakilan dari setiap soa dan mereka juga terdiri dari para orang tua dan anak-anak muda. Kombinasi antara para orang tua dan anak-anak muda dalam lembaga saniri 
bertujuan supaya ada sistem regenerasi yang nantinya dapat melanjutkan tugas-tugas dan peran lembaga saniri di masa depan. Selain itu, dengan cara tersebut anak-anak muda juga diharapkan dapat belajar dari para orang tua tentang adat-istiadat serta tugas-tugas dan peran mereka di lembaga saniri.

\subsection{Peran Lembaga Adat di Negeri Lafa.}

Dalam masyarakat atau khususnya masyarakat adat terdapat apa yang disebut lembaga adat. Lazimnya, eksistensi lembaga adat selalu melekat pada setiap kehidupan masyarakat adat. Hal ini karena setiap kehidupan masyarakat adat pasti memiliki kebutuhan pokok yang apabila dikelompokkan maka akan terhimpun menjadi sebuah lembaga adat. Eksistensi lembaga adat ini dapat dikatakan tumbuh sejalan dengan kehidupan manusia atau warga masyarakat. Hal ini terjadi karena dalam hidupnya, setiap manusia membutuhkan keteraturan, khususnya yang terkait dengan pola-pola perilaku sehingga dirumuskan norma-norma dalam masyarakat. Norma-norma ini awalnya terbentuk secara tidak sengaja namun lambat-laun norma tersebut dibuat secara sadar oleh manusia karena dianggap penting untuk memberikan keteraturan bagi mereka.

Eksistensi lembaga adat sebagaimana yang ada di negeri-negeri adat di Maluku tentu bukan hanya ada untuk melengkapi sistem pemerintahan adat, namun lebih dari pada itu harus melaksanakan dan meningkatkan perannya bagi kepentingan warga masyarakat. Realitas yang selama ini terjadi, khususnya yang tampak di Negeri Lafa, lembaga adat (saniri) masih kurang melaksanakan perannya. Hal ini tampak dari begitu banyak masalah yang terkait dengan adat masih belum mampu diselesaikan oleh lembaga adat tersebut. Bahkan ada juga anggota-anggota saniri yang belum mampu melaksanakan tugas dan tanggungjawabnya dengan baik karena keterbatasan pengetahuan yang dimiliki sehingga sangat mempengaruhi peran lembaga saniri tersebut.

Salah satu faktor yang juga cukup mempengaruhi implementasi peran lembaga saniri ini adalah keanggotaan saniri yang terdiri dari para orang tua dan anak-anak muda (pemuda). Faktor ini ternyata cukup mempengaruhi implementasi peran lembaga saniri karena umumnya anggota saniri yang merupakan kelompok pemuda masih belum memahami tugas dan tanggungjawabnya, bahkan adat istiadat di negeri mereka. Selain itu, kaum muda (pemuda) lebih banyak menghabiskan waktu dengan mabuk-mabukan setelah mengkonsumsi minuman keras daripada belajar dari orang tua. 
Kenyataan ini menunjukkan adanya jarak antara kaum muda dan para orang tua di Negeri Lafa baik sebagai anggota saniri maupun dalam kehidupan bersama. Kenyataan ini pun lebih memprihatinkan ketika pejabat raja sebagai pimpinan pemerintahan kurang memberikan perhatian kepada kinerja lembaga adat, khususnya untuk melakukan koordinasi dengan lembaga saniri, tetapi lebih menghabiskan waktu untuk mengurus segala urusan pribadi atau kepentingan-kepentingan politik kelompok tertentu. Hal ini menyebabkan masyarakat adat Negeri Lafa menjalani kehidupan dengan penuh keresahan dan merasa tidak nyaman dengan realita yang dihadapi terhadap kinerja raja maupun lembaga saniri yang dirasakan kurang bertanggungjawab terhadap semua yang terjadi di Negeri Lafa.

Sejalan dengan itu, Ajawaila (2005) menjelaskan bahwa, salah satu penyebab terjadinya konflik di antara orang bersaudara adalah karena melemahnya ketahanan budaya dan melemahnya peran lembaga-lembaga adat yang merupakan wadah untuk memenuhi kebutuhan, membangun kebersamaan, membangun saling percaya sebagai orang bersaudara. Apa yang dikatakan oleh Ajawaila, sebagaimana yang terjadi pada kehidupan masyarakat adat Negeri Lafa. Sebagai salah satu negeri adat, Negeri Lafa juga memiliki ciri-ciri atau karakteristik yang sama dengan negeri adat lainnya di Maluku. Ciriciri atau karakteristik tersebut misalnya, simbol-simbol adat di antaranya, rumah adat, bendera negeri, piring-piring tua peninggalan leluhur, dan bahasa, kemudian ritual-ritual adat seperti, pelantikan raja, perkawinan, dan pembangunan rumah adat. Kesenian yang dimiliki di antaranya, tarian cakalele, maku-maku, dan tari sewa serta tentunya lembaga adat seperti saniri.

\subsection{Pemerintahan Adat Negeri Lafa.}

Negeri-negeri adat di Maluku memiliki sistem pemerintahan adat yang dipimpin oleh seorang pimpinan yang biasa disebut raja. Raja merupakan salah seorang tokoh yang sangat berperan dan berpengaruh dalam sistem pemerintahan adat. Dalam melaksanakan tugas-tugas pemerintahan seorang raja biasanya dibantu oleh para stafnya. Pada negeri adat, raja biasanya berasal dari mata rumah parentah (marga perintah) dan berlaku turuntemurun. Hal inipun sudah diakui sejak jaman para leluhur pada saat negeri adat mulai terbentuk dan ada pembagian-pembagian peran dalam masyarakat adat tersebut. Namun ketika munculnya penjajah, khususnya bangsa Belanda, sistem pemerintahan mengalami perubahan terutama pada kepemimpinan raja. Pada masa penjajahan bangsa Belanda, 
dengan kekuasaan yang dimiliki mereka mampu merubah sistem pemerintahan raja yang semula dipimpin oleh seseorang yang berasal dari matarumah parentah menjadi pilihan langsung yang ditentukan oleh penjajah Belanda. Penunjukkan ini sebagai bagian dari strategi politik penjajah Belanda untuk memecah belah dan menguasai masyarakat adat dengan menunjuk salah seorang warga yang dianggap taat serta dapat bekerjasama dengan pihak Belanda.

Politik yang dilakukan penjajah Belanda ternyata cukup berhasil sebab hingga saat ini pun masih terjadi masalah dalam sistem pemerintahan adat di banyak negeri di Maluku. Masalah yang muncul seperti misalnya pada acara pemilihan raja yang dilaksanakan oleh beberapa negeri adat di Maluku. Pada saat akan diadakan acara pemilihan raja di sebuah negeri adat, muncul banyak anggota masyarakat adat yang ingin mencalonkan diri mereka, walau secara aturan adat ada di antara mereka yang tidak berhak mengikuti pencalonan tersebut. Artinya, secara adat syarat untuk mengikuti pemilihan raja yaitu mereka harus berasal dari matarumah parentah, kalau pun ada calon lain yang bukan berasal dari matarumah parentah, mereka ini harus meminta ijin terlebih dahulu dari matarumah parentah dan apabila diijinkan barulah mereka boleh mengikuti pencalonan.

Selain itu, ada juga mereka yang mencalonkan diri karena pada masa penjajahan Belanda keluarga atau leluhur mereka pernah diangkat menjadi raja. Fenomena sosial budaya seperti inilah yang selama ini banyak terjadi di negeri-negeri adat di Maluku sehingga sistem pemilihan raja seakan tidak lagi memiliki nilai-nilai kesakralan karena telah diselimuti oleh nilai kepentingan politik kelompok-kelompok tertentu dalam kehidupan masyarakat adat. Fenomena inipun seperti yang terjadi pada sistem pemerintahan adat di Negeri Lafa. Negeri Lafa yang telah ada sejak tahun 1798 pada saat itu dipimpin oleh Ongtua Leahua Ilela. Masyarakat adat di Negeri Lafa mengakui sistem pemerintahan adat dipimpin oleh salah seorang raja yang berasal dari keturunan pendiri negeri yang merupakan mata rumah parentah (keluarga/marga perintah) dan telah berlaku sejak dahulu hingga sekarang.

Senada dengan hal tersebut, Cooley (1987:225-226) mengatakan bahwa pada umumnya telah disepakati bahwa raja itu harus berasal dari salah satu matarumah tertentu yang dianggap memiliki hak keturunan dan tanggung jawab tradisional untuk memerintah. Di kebanyakan negeri/desa, sedikitnya terdapat dua matarumah dengan hak istimewa demikian, yakni matarumah yang berkuasa sebelum masa penjajahan kolonial Eropa dan matarumah yang berkuasa karena diangkat oleh penguasa Belanda. Akan tetapi di 
sejumlah negeri/desa, sepanjang ingatan orang-orang, hanya satu matarumah saja yang memerintah.

Apa yang dikatakan Cooley jelas menunjukkan bahwa pada negeri-negeri adat di Maluku posisi sebagai seorang raja hanya boleh ditempati oleh orang-orang yang berasal dari matarumah parentah. Hal tersebut juga berlaku pada Negeri Lafa sebagai salah satu negeri adat di Maluku sehingga seluruh warga masyarakat Negeri Lafa harus mengetahui dan memahami serta melaksanakannya sesuai dengan aturan-aturan adat yang berlaku di negeri mereka. Pemerintahan adat di Negeri Lafa ternyata cukup kompleks. Adanya berbagai persoalan yang muncul dalam sistem pemerintahan adat seringkali menimbulkan keresahan dan mengganggu kenyaman hidup warga masyarakat. Persoalan-persoalan yang saat ini muncul seperti adanya keinginan warga masyarakat untuk mencalonkan diri menjadi raja di Negeri Lafa walaupun bukan berasal dari matarumah parentah dan kurangnya ketersediaan sumberdaya manusia yang mampu untuk mengemban tugas kepemimpinan sebagai seorang raja. Pada negeri-negeri adat di Maluku, seperti yang diketahui bahwa umumnya mengakui legalitas penuh kepemimpinan raja menjadi milik warga yang berasal dari matarumah parentah. Hal ini tidak dapat dibantahkan oleh siapapun meskipun dia warga adat karena merupakan amanat para leluhur dan telah menjadi nilai-nilai dan norma-norma adat yang perlu dijaga serta dilestarikan.

Realita kehidupan masyarakat adat Negeri Lafa dalam era modernisasi saat ini banyak ditandai oleh adanya persaingan-persaingan dan perebutan kekuasaan yang hanya untuk memenuhi kepentingan kebutuhan hidup serta kepentingan politik sekelompok orang. Realita tersebut suka atau tidak suka membuat orang atau warga masyarakat adat Negeri Lafa tidak lagi taat dan peduli terhadap nilai-nilai serta norma-norma adat yang berlaku di negeri mereka. Nilai-nilai dan norma-norma adat seakan hanya menjadi slogan yang diingat tetapi tidak ditaati serta dihargai oleh warga masyarakat adat. Hal ini menyebabkan warga masyarakat adat selalu terlibat dalam konflik yang terkadang sifatnya bukan hanya laten namun juga manifes. Dalam kenyataannya juga seringkali perebutan kekuasaan itu tidak diimbangi oleh kualitas sumberdaya manusia yang siap dari segi pengetahuan, khususnya pengetahuan tentang adat-istiadat di Negeri Lafa. Kenyataan yang sangat tampak terjadi ketika akan diadakan pemilihan raja, dimana saat itu banyak sekali warga masyarakat adat yang ingin mencalonkan diri, terutama dari kaum pemuda. Hal ini tentu saja merupakan sesuatu yang wajar namun perlu mengetahui mekanisme dan syarat menjadi raja, bukan karena keinginan serta dorongan dari orang atau pihak lain, 
baik di internal maupun eksternal Negeri Lafa. Selain itu, walaupun pengetahuan tentang adat bukan menjadi syarat utama, namun mutlak harus dimiliki oleh seorang calon raja yang berkeinginan untuk memimpin sebuah negeri adat. Saat ini banyak sekali kaum pemuda di Negeri Lafa yang kurang pengetahuannya tentang adat-istiadat di negeri mereka.

Para anak muda dianggap kurang peduli tentang adat istiadat yang ada di negeri mereka sehingga pengetahuannya juga terbatas. Hal ini tentu sangat berpengaruh apalagi mereka memiliki keinginan yang kuat untuk menjadi raja di negerinya karena menjadi raja bukan soal kekuasaan semata, namun yang lebih penting adalah soal kualitas dan pengetahuan yang nanti mampu digunakan untuk memimpin masyarakat. Ketidakpedulian kaum muda menyebabkan pengetahuan tentang sejarah dan adat istiadat Negeri Lafa hanya diketahui oleh para orang tua sehingga wajar saja kalau ada anggapan yang menyatakan bahwa para orang tua yang layak menjadi raja di Negeri Lafa. Hal ini menunjukkan bahwa keberadaan para orang tua kurang dimanfaatkan oleh kaum muda untuk belajar tentang sejarah dan adat istiadat di Negeri Lafa. Kaum muda ada dalam dunianya seakan tidak ingin berbaur dengan para orang tua sehingga keinginan untuk menjadi raja merupakan upaya meraih kekuasaan tanpa diimbangi kualitas pengetahuan yang dimiliki untuk memimpin negeri, terutama sebuah negeri adat. Hal ini merupakan realitas objektif yang tampak dalam kehidupan masyarakat Negeri Lafa.

\section{Kesimpulan.}

Dalam banyak studi tentang masyarakat menunjukkan bahwa eksistensi masyarakat adat khususnya tidak terlepas dari karakteristik serta adat istiadat yang dimiliki. Sebuah masyarakat adat tumbuh dan berkembang dengan berbagai tradisi yang dimiliki sejak zaman leluhur. Tradisi ini kemudian terpelihara dan dilestarikan dalam kehidupan bersama supaya dapat menjadi pedoman bagi warga masyarakatnya. Dalam eksistensinya, masyarakat adat memiliki berbagai macam kebudayaan yang tumbuh berkembang bersama dan menjadi karakteristik serta identitas diri warga masyarakat adat tersebut.

Sebagaimana yang dijelaskan sebelumnya bahwa sebagai salah satu negeri adat di Maluku, Negeri Lafa telah eksis sejak tahun 1798. Sejak saat itu, Negeri Lafa telah memiliki berbagai macam budaya dan adat istiadat yang kemudian tumbuh serta berkembang bersama warga masyarakat Negeri Lafa. Sistem perkawinan adat, proses 
pemilihan raja, dan kegiatan kesenian adat lainnya seperti tari-tarian cakalele, makumaku, serta sewa merupakan wujud eksistensi masyarakat adat Negeri Lafa.

Dalam berbagai acara atau ritual adat, tari-tarian ini selalu ditampilkan, selain untuk mengisi acara sebenarnya ingin mempertegas eksistensi serta identitas diri masyarakat adat Negeri Lafa. Sebagai negeri adat, tentu saja budaya atau adat istiadat merupakan faktor penting yang dapat menunjukkan eksistensi masyarakat adat di Negeri Lafa. Hal ini karena budaya atau adat istiadat tersebut telah terintregrasi dan menjadi bagian yang tidak terpisahkan dalam kehidupan bersama masyarakat adat. Berbagai macam kebudayaan yang menunjukkan eksistensi masyarakat adat tersebut seperti kesenian, ritual adat, bahasa, simbol-simbol adat dan lain-lain. Semua wujud kebudayaan ini selalu ada dan telah terintegrasi sehingga mempertegas eksistensi masyarakat adat tersebut, termasuk masyarakat Negeri Lafa. Masyarakat adat Negeri Lafa sejak dahulu hingga sekarang tumbuh dan berkembang dengan kebudayaan atau adat istiadat yang dimiliki. Berbagai wujud kebudayaan atau adat istiadat yang dimiliki telah menunjukkan eksistensi masyarakat adat Negeri Lafa.

Terkait hal tersebut, Cooley (1987:94) menyampaikan hasil penelitiannya di Negeri Allang dan Negeri Aboru bahwa beberapa informan orang tua di kedua negeri mengisahkan pengalaman ketika bersekolah. Mereka akan dipukuli oleh guru-guru mereka bila kedapatan berbicara dalam bahasa asli. Jika dengan tidak sengaja berbicara dalam bahasa asli mereka akan diberikan peringatan keras untuk tidak menggunakan bahasa lain selain bahasa Melayu, walaupun dalam rumah mereka sendiri. Sistem pendidikan yang demikian ini membuat mereka menyatakan penyesalannya karena berakibat mereka tidak lagi menguasai bahasa asli mereka sendiri, padahal bahasa merupakan salah satu unsur penting dalam menjalankan dan mempertahankan adat.

Apa yang disampaikan Cooley menunjukkan bahwa sebenarnya bahasa adat merupakan unsur penting dalam masyarakat adat yang harus dijaga kelestariannya supaya tidak hilang atau punah begitu saja. Hal ini tentu saja yang harus dipahami oleh warga masyarakat Negeri Lafa khususnya anak-anak muda yang menjadi anggota saniri. Anakanak muda harus mengetahui dan mempelajari bahasa adat supaya dapat membantu mereka dalam melaksanakan tugas dan tanggung jawab sebagai anggota saniri. Dengan mengetahui dan mempelajari bahasa adat maka berbagai hal atau masalah yang muncul dapat teratasi karena bahasa adat mampu menyatukan dan mempererat hubunganhubungan antar warga masyarakat, khususnya warga msyarakat Negeri Lafa. 
Beberapa pernyataan sebagai kesimpulan dari penjelasan yang dikemukakan terkait dinamika masyarakat Negeri Lafa sebagai suatu masyarakat adat adalah sebagai berikut: (1) Negeri Lafa sebagai salah satu negeri adat ternyata memiliki karakteristik yang tidak jauh berbeda dengan negeri-negeri adat lainnya di Maluku. Eksistensi lembaga adat menjadi salah satu karakteristik negeri adat. Namun apalah artinya kalau eksistensi lembaga adat ini tidak dibarengi dengan implementasi peran yang dapat membantu menyelesaikan berbagai masalah yang muncul dalam kehidupan warga masyarakat adat. (2) Dalam pemerintahan adat Negeri Lafa muncul berbagai masalah terutama pada sistem pencalonan raja. Hal ini dikarenakan ketidaktaatan terhadap aturan adat terkait mata rumah parentah. Warga yang bukan berasal dari matarumah parentah berkeinginan juga untuk menjadi raja. (3) Para generasi muda, khususnya anak-anak adat banyak yang tidak mengetahui dan tidak peduli tentang adat istiadat di negeri mereka. Para pemuda lebih banyak menghabiskan waktu untuk mengkonsumsi minuman keras hingga mabuk dan sering membuat keributan di lingkungan tempat tinggal. (4) Negeri Lafa sebagai negeri adat yang sudah dikukuhkan sejak tahun 1798 dan berkembang dengan berbagai adat istiadat serta budaya harus tetap dipertahankan eksistensinya.

\section{Daftar Pustaka}

Abdulsyani. 2002. Sosiologi, Skematika, Teori, dan Terapan, PT Bumi Aksara, Cetakan Kedua, Jakarta.

Ajawaila, J. W. 2005. Dinamika Budaya Orang Maluku. Dalam Lembaga Kebudayaan Daerah Maluku (ed.), Maluku Menyambut Masa Depan. LKDM, Ambon.

Basrowi. 2005. Pengantar Sosiologi. Penerbit Ghalia Indonesia, Ciawi-Bogor.

Cooley, Frank L. 1987. Mimbar dan Takhta, Hubungan Lembaga-Lembaga Keagamaan dan Pemerintah di Maluku Tengah. Pustaka Sinar Harapan, Jakarta.

Effendi, Ziwar. 1987. Hukum Adat Ambon Lease. Pradnya Paramita, Jakarta.

Fathoni Abdurrahmat. 2006. Antropologi Sosial Budaya. Rineka Cipta, Jakarta.

Iskandar. 2009. Metode Penelitian Kualitatif. Gaung Persada, Jakarta.

Lokollo, J. E. 2012. Eksistensi Negeri Adat di Maluku dalam Konteks Hukum dan Demokrasi Pancasila. Dalam Berlayar Dalam Ombak, Berkarya Bagi Negeri. Ralahalu Institut, Ambon-Maluku.

Miles, Matthew B \& Huberman, A Michael. 2007. Analisis Data Kualitatif. Universitas Indonesia, Jakarta. 
Moleong, Lexy J. 1998. Metodologi Penelitian kualitatif. Remaja Rosdakarya, Bandung. Moleong, Lexy J. 2000. Metodologi Penelitian Kualitatif. Remaja Rosdakarya, Bandung. Muhammad Abdulkadir. 2008. Ilmu Sosial Budaya Dasar. Citra Aditya Bakti, Bandung. Peraturan Daerah Kabupaten Maluku Tengah Nomor 01 Tahun 2006 Tentang Negeri.

Poerwanto, Hari. 2008. Kebudayaan dan Lingkungan Dalam Perspektif Antropologi. Pustaka Pelajar, Yogyakarta.

Ranjabar Jacobus. 2006. Sistem Sosial Budaya Indonesia. Ghalia Indonesia, Bogor.

Rusdiyanta, Syahrial \& Syarbaini. 2009. Dasar-Dasar Sosiologi. Graha Ilmu, Yogyakarta.

Saifuddin Ahmad Fedyani. 2005. Antropologi Kontemporer. Prenada Media Group, Jakarta.

Sihasale, W. R. 2005. Pola Pengelompokan Masyarakat Adat dan Sistem Pemerintahan Adat di Maluku. Dalam Lembaga Kebudayaan Daerah Maluku (ed.), Maluku Menyambut Masa Depan. LKDM, Ambon.

Sztompka, Piotr. 2011. Sosiologi Perubahan Sosial. Prenada Media Group, Jakarta.

Watloly, Aholiab. 2007. Filosofi Masyarakat Kepulauan (Sebuah Telaah Filsafat Dalam Rangka Indigenisasi Sosiologi Kepulauan). Orasi Ilmiah pada Dies Natalis Ke-44 Universitas Pattimura.

Watloly, Aholiab. 2013. Cermin Eksistensi Masyarakat Kepulauan Dalam Pembangunan Bangsa, Perspektif Indigenous Orang Maluku. Intimedia Cipta Nusantara, Jakarta 